\title{
Awareness Regarding Beti Bachao Beti Padhao Scheme in Rewari Districts
}

\author{
Jyoti Rani*, Manju Dahiya and Beena Yadav \\ Department of EECM, CCS Haryana Agricultural University, Hisar-125004 (Haryana), India \\ *Corresponding author
}

\section{A B S T R A C T}

\begin{tabular}{|c|}
\hline Keywords \\
\hline $\begin{array}{l}\text { Beti Bachao Beti } \\
\text { Padhao, Female } \\
\text { feticide, Girls } \\
\text { education }\end{array}$ \\
\hline Article Info \\
\hline $\begin{array}{l}\text { Accepted: } \\
\text { 17 June } 2019 \\
\text { Available Online: } \\
\text { 10 July } 2019\end{array}$ \\
\hline
\end{tabular}

Education for women is the best way to improve the health, nutrition and economic status of a household that constitute a micro unit of a nation economy. In this context, it can be argued that lack of women education can be an impediment to the country's economic development. Mr. Narender Modi, Prime Minister of India has given stress on the need of educating and protecting the girl child. Therefore, the present study has been planned with the objectives to develop and expose the media package on "Beti Bachao Beti Padhao" to rural women. Sufficient increase in knowledge regarding $B B B P$ was recorded after exposure for sub- components viz., general information, information about female feticide and abortion, awareness about benefits given under the scheme, provision of award under $B B B P$. The media package had significant effect on the increase in knowledge of the respondents. Increase in knowledge was maximum for programme under $B B B P$ in general information, awareness about benefits of the scheme, information about female feticide and abortion, whereas in Rewari district maximum increase in knowledge was observed for general information followed by awareness about benefits of the scheme, programmes under the scheme, information about female feticide and abortion.

\section{Introduction}

Women constitute almost half of the population of the world. Education for women is the best way to improve the health, nutrition and economic status of a household that constitute a micro unit of a nation economy. In this context, it can be argued that lack of women education can be an impediment to the country's economic development. In India, women achieve far less education that of men. As per the Census report 2011, the literacy rate of women is 65.46 per cent and that of men is 82.14 per cent.
Shri Narender Modi, Honorable Prime Minister of India has given stress on the need of educating and protecting the girl child. When the country is heading towards being the superpower if not in the near future, in the long run. Yeah this is the miserable condition of the daughters in some parts of the country where the girls are not treated equal to boys, not allowed to go to the schools beyond primary classes, deprived of all the facilities which their brothers enjoy with extreme liberty and in some cases the girls are not allowed to take birth and they get killed in the womb of their mothers 
For this, stress should be on the importance of effective use of communication technology for the advancement of educational goals by reaching out to the people in the remote areas. We have to take every necessary step to catch up with the rapidly advancing frontiers of knowledge. Judiciary in India declared 2007 as the "Awareness year of Female foeticide" We should produce programmes based on expert lectures on various topics and broadcast these for the benefit of rural people in remote areas of the state. This can be done through effective utilization of communication technology so that the less privileged women in remote areas receive the same quality of learning as is available to the economically better placed segments of the women community living in the urban centres.

Therefore, the present study was planned with the following objective:

To assess the knowledge of respondent on "Beti Bachao Beti Padhao" scheme

\section{Materials and Methods}

The present study was carried out in the Haryana state. Rewari districts were selected purposively with having lowest sex ratio. From Rewari district Jatusana block were selected purposively with having lowest sex ratio. From Jatusana two villages selected randomly Dahina and Maseet Matching sample of 30 rural women from two (Dahina, Maseet) villages with same age group and same education level (who can be read and write) were selected. Therefore the total sample compared of 60 rural women.

As per requirements of the study, sociopersonal, economic and communication variables namely age, education of respondents, occupation of respondents, family occupation, caste, house type, type of family, size of family, no. of children annual income, land holding, mass media exposure and information source utilization were selected as independent variables. Effectiveness of media package was selected as dependent variables. Effectiveness of media package was assessed in terms of increase in knowledge. A well structured interview schedule was constructed for data collection on the basis of objectives, independent and dependent variables of the study. The collected data were quantified and interpreted by using suitable statistical tools such as frequency, percentage, weighted mean score, rank, paired ' $t$ ' test and chi-square as per objectives of the study.

\section{Results and Discussion}

Knowledge of respondents regarding $B B B P$ in Rewari district

Increase in knowledge of respondents regarding $B B B P$ in Dahina

Pre-exposure and post exposure mean scores and ' $t$ ' test was computed for general information, information about female feticide and abortion, Awareness about benefits of the scheme and Programmes under $B B B P$ in village Dahina which are presented in Table 1.

Sufficient increase in knowledge regarding general information about the scheme Beti Bachao Beti Padhao was recorded for subcomponents of scheme viz., year of the start, target of the scheme, benefits given under scheme, main objective under the scheme, and lowest sex ratio in Haryana of Dahina village. Maximum knowledge was recorded for main objective of the scheme followed by target of the scheme, benefits given under the scheme. It may, therefore be concluded that women succeeded in acquiring knowledge after exposure to general information about of 
the scheme Beti Bachao Beti Padhao. The components main objective under the scheme and target of the scheme was statistically significant at $5 \%$ level of significance.

As far as knowledge regarding information about female feticide and abortion was concerned, it was recorded for subcomponents viz; methods of sex determination, effects of abortion on the health of women, legality of abortion, laws related to abortion in Dahina village. Among the components maximum increase in knowledge was observed regarding effects of abortion on the health of women and legality of abortion. It may, therefore be concluded that women succeeded in acquiring knowledge after exposure to $\mathrm{T}_{1}$. The component effects of abortion on the health of women and legality of abortion were statistically significant at 5\% level of significance.

Table further shows awareness about benefits of the scheme. Majority of the respondents had an increase in knowledge for the components that the scheme Assures protection,education,survival,nutritional status of girl child followed by, make girl child aware of sanitation and other health aspects, reduction in rape cases, crimes against girl child, awareness about rights of women and girl child, helps the girl child to remain unmarried till the age of 18 years, important for development of girl child, reward of Rs. 1crore is for an innovative village attaining a balanced sex ratio, beneficial for both rural as well as urban girl child in Dahina village. It may, therefore be concluded that women succeeded in acquiring knowledge after exposure for the parameters that the scheme assures -protection, education, survival, nutritional status of girl child and to awareness about actual benefits of the scheme helps the girl child to remain unmarried till the age of 18 years. All the components were statistically significant except the scheme beneficial for both rural as well as urban girl child, important for development of girl child.

Awareness about programme under $B B B P$ showed the maximum increase in knowledge for Haryana kanya kosh followed by Sukanya Samiridhi Yojna and provision of award in $B B B P$. It may, therefore be concluded that women succeeded in acquiring knowledge after exposure to Programmes under $B B B P$. All components were statistically significant at level of $5 \%$ level of significance.

\section{Increase in knowledge of respondents regarding $B B B P$ in Maseet}

Pre-exposure and post exposure mean scores and ' $t$ ' test was computed for general information, Information about female feticide and abortion, Awareness about benefits of the scheme and Programmes under $B B B P$ in village Maseet which are presented in Table 2.

Sufficient increase in knowledge regarding general information about the scheme Beti Bachao Beti Padhao was recorded for subcomponents of scheme viz., year of the start, target of the scheme, benefits given under scheme, main objective under the scheme, and lowest sex ratio in Haryana of Maseet village. Maximum knowledge was recorded for main objective of the scheme followed by target of the scheme, year of the start, benefits given under the scheme. It may, therefore be concluded that women succeeded in acquiring knowledge after exposure to general information about of the scheme Beti Bachao Beti Padhao. The components in main objective of the scheme followed by target of the scheme, year of the start the scheme were statistically significant at 5\% level of significance (Fig. 1). 
As far as knowledge regarding information about female feticide and abortion was concerned, it was recorded for subcomponents viz., methods of sex determination, effects of abortion on the health of women, legality of abortion, laws related to abortion in Maseet village. Among the components maximum increase in knowledge was observed regarding laws related to abortion, effects of abortion on the health, legality of abortion. It may, therefore be concluded that women succeeded in acquiring knowledge after exposure to $T_{1}$. The component laws related to abortion, effects of abortion on the health, were statistically significant at $5 \%$ level of significance.

Table.1 Increase in knowledge of respondents regarding BBBP in Dahina

\begin{tabular}{|c|c|c|c|c|c|}
\hline \multirow{2}{*}{$\begin{array}{l}\text { Sr. } \\
\text { No. }\end{array}$} & \multirow[t]{2}{*}{ Knowledge regarding BBBP (Maximum Score) } & \multicolumn{3}{|c|}{ Mean score } & \multirow[t]{2}{*}{ t value } \\
\hline & & $\begin{array}{c}\text { Pre } \\
\text { exposure }\end{array}$ & $\begin{array}{c}\text { Post } \\
\text { exposure }\end{array}$ & $\begin{array}{l}\text { increase in } \\
\text { knowledge }\end{array}$ & \\
\hline a. & General information & & & & \\
\hline 1. & Year of the start (1) & 0.50 & 0.80 & 0.30 & 2.83 \\
\hline 2. & Target of the scheme (3) & 0.93 & 2.23 & 1.30 & $7.20 *$ \\
\hline 3. & Benefits given under scheme (3) & 1.70 & 2.36 & 0.67 & 3.01 \\
\hline 4. & Main objective under the scheme (7) & 3.10 & 5.65 & 2.55 & $8.27 *$ \\
\hline 5. & lowest sex ratio in Haryana(1) & 0.43 & 0.66 & 0.23 & 1.75 \\
\hline b. & Information about female feticide and abortion & & & & \\
\hline 1. & Methods of sex determination (1) & 0.66 & 0.76 & 0.10 & 0.90 \\
\hline 2. & Effects of abortion on the health of women (1) & 0.36 & 0.93 & 0.56 & $6.15^{*}$ \\
\hline 3. & Legality of abortion (3) & 1.16 & 1.96 & 0.80 & $4.25 *$ \\
\hline 4. & Law related to abortion (3) & 0.60 & 1.16 & 0.56 & 3.31 \\
\hline c. & Awareness about benefits of the scheme & & & & \\
\hline 1. & $\begin{array}{l}\text { Helps the girl child to remain unmarried till the age } \\
\text { of } 18 \text { years (1) }\end{array}$ & 0.33 & 0.76 & 0.43 & $3.26 *$ \\
\hline 2. & Important for development of girl child (1) & 0.46 & 0.76 & 0.30 & 2.34 \\
\hline 3. & $\begin{array}{c}\text { Assures -protection,education, survival,nutritional } \\
\text { status of girl child (4) }\end{array}$ & 1.36 & 3.16 & 1.80 & $7.44 *$ \\
\hline 4. & $\begin{array}{c}\text { Make girl child aware of sanitation and other } \\
\text { health aspects (1) }\end{array}$ & 0.23 & 0.86 & 0.63 & $6.23 *$ \\
\hline 5. & $\begin{array}{l}\text { Awareness about rights of women and girl child } \\
\text { (1) }\end{array}$ & 0.30 & 0.63 & 0.33 & $3.34 *$ \\
\hline 6. & $\begin{array}{l}\text { Reduction in rape cases, crimes against girl child } \\
\text { (1) }\end{array}$ & 0.33 & 0.73 & 0.40 & $3.52 *$ \\
\hline 7. & $\begin{array}{l}\text { Beneficial for both rural as well as urban girl child } \\
\text { (1) }\end{array}$ & 0.43 & 0.66 & 0.23 & 2.04 \\
\hline 8. & $\begin{array}{l}\text { Reward of Rs. 1crore for an innovative village } \\
\text { attaining a balanced sex ratio (1) }\end{array}$ & 0.23 & 0.63 & 0.40 & 2.83 \\
\hline d. & Programmes under BBBP & & & & \\
\hline 1. & Sukanya samridhi yojna (5) & 1.60 & 3.53 & 1.93 & $9.79 *$ \\
\hline 2. & Haryana kanya kosh (4) & 0.96 & 3.30 & 2.30 & $11.36^{*}$ \\
\hline 3. & Provision of award in $B B B P(4)$ & 1.26 & 3.26 & 2.0 & $9.32 *$ \\
\hline
\end{tabular}

*Significant at $5 \%$ level of significance 
Table.2 Increase in knowledge of respondents regarding $B B B P$ in Maseet

\begin{tabular}{|c|c|c|c|c|c|}
\hline \multirow{2}{*}{$\begin{array}{l}\text { Sr. } \\
\text { No. }\end{array}$} & \multirow[t]{2}{*}{ Knowledge regarding BBBP (Maximum Score) } & \multicolumn{3}{|c|}{ Mean score } & \multirow[t]{2}{*}{ t value } \\
\hline & & $\begin{array}{c}\text { Pre } \\
\text { exposure }\end{array}$ & $\begin{array}{c}\text { Post } \\
\text { exposure }\end{array}$ & $\begin{array}{l}\text { Increase in } \\
\text { knowledge }\end{array}$ & \\
\hline a. & General information & & & & \\
\hline 1. & Year of the start (1) & 0.33 & 0.83 & 0.50 & $5.38 *$ \\
\hline 2. & Target of the scheme (3) & 0.66 & 2.23 & 1.56 & $8.52 *$ \\
\hline 3. & Benefits given under scheme (3) & 1.60 & 2.56 & 0.96 & $5.29 *$ \\
\hline 4. & Main objective under the scheme (7) & 3.10 & 5.80 & 2.70 & $10.09 *$ \\
\hline 5. & lowest sex ratio in Haryana (1) & 0.43 & 0.80 & 0.36 & 3.26 \\
\hline b. & Information about female feticide and abortion & & & & \\
\hline 1. & Methods of sex determination (1) & 0.66 & 0.83 & 0.16 & 1.72 \\
\hline 2. & Effects of abortion on the health of women (1) & 0.36 & 0.80 & 0.43 & $4.17 *$ \\
\hline 3. & Legality of abortion (3) & 1.16 & 2.0 & 0.83 & 3.87 \\
\hline 4. & Laws related to abortion (3) & 0.60 & 1.20 & 0.60 & $4.53 *$ \\
\hline c. & Awareness about benefits of the scheme & & & & \\
\hline 1. & $\begin{array}{l}\text { Helps the girl child to remain unmarried till the } \\
\text { age of } 18 \text { years (1) }\end{array}$ & 0.40 & 0.70 & 0.30 & 2.34 \\
\hline 2. & Important for development of girl child (1) & 0.46 & 0.73 & 0.27 & 1.95 \\
\hline 3. & $\begin{array}{l}\text { Assures- protection,education,survival,nutritional } \\
\text { status of girl child (4) }\end{array}$ & 1.73 & 3.13 & 1.40 & $5.14 *$ \\
\hline 4. & $\begin{array}{c}\text { Make girl child aware of sanitation and other } \\
\text { health aspects (1) }\end{array}$ & 0.36 & 0.83 & 0.47 & $4.06 *$ \\
\hline 5. & $\begin{array}{l}\text { Awareness about rights of women and girl child } \\
\text { (1) }\end{array}$ & 0.50 & 0.70 & 0.20 & 1.49 \\
\hline 6. & $\begin{array}{l}\text { Reduction in rape cases, crimes against girl child } \\
\text { (1) }\end{array}$ & 0.36 & 0.80 & 0.43 & $3.49 *$ \\
\hline 7. & $\begin{array}{l}\text { Beneficial for both rural as well as urban girl child } \\
\text { (1) }\end{array}$ & 0.50 & 0.73 & 0.23 & 1.82 \\
\hline 8. & $\begin{array}{c}\text { Reward of Rs. } 1 \text { crore for an innovative village } \\
\text { attaining a balanced sex ratio (1) }\end{array}$ & 0.46 & 0.96 & 0.50 & $4.78 *$ \\
\hline d. & Programmes under BBBP & & & & \\
\hline 1. & Sukanya samridhi yojna (5) & 1.73 & 3.50 & 1.77 & $9.61 *$ \\
\hline 2. & Haryana kanya kosh (4) & 1.90 & 3.50 & 1.60 & $8.73 *$ \\
\hline 3. & Provision of award in $B B B P(4)$ & 1.26 & 3.16 & 1.90 & $14.62 *$ \\
\hline
\end{tabular}

*Significant at $5 \%$ level of significance

Table.3 Village wise comparison increase in knowledge regarding BBBP scheme

\begin{tabular}{|c|c|c|c|}
\hline \multicolumn{2}{|c|}{$\begin{array}{c}\text { Sr. } \\
\text { No. }\end{array}$} & $\begin{array}{c}\text { Knowledge regarding } \\
\text { BBBP }\end{array}$ & \multicolumn{2}{|c|}{ Mean Score } \\
\cline { 3 - 4 } & & Dahina & Maseet \\
\hline 1. & General information & 4.80 & 5.90 \\
\hline 2. & $\begin{array}{c}\text { Information about female } \\
\text { feticide and abortion }\end{array}$ & 1.70 & 1.80 \\
\hline 3. & $\begin{array}{c}\text { Awareness of about } \\
\text { benefits of the scheme }\end{array}$ & 3.60 & 3.80 \\
\hline 4. & Programmes under $B B B P$ & 6.27 & 5.27 \\
\hline
\end{tabular}


Fig.1 Knowledge regarding $B B B P\left(\mathrm{~T}_{1}\right)$

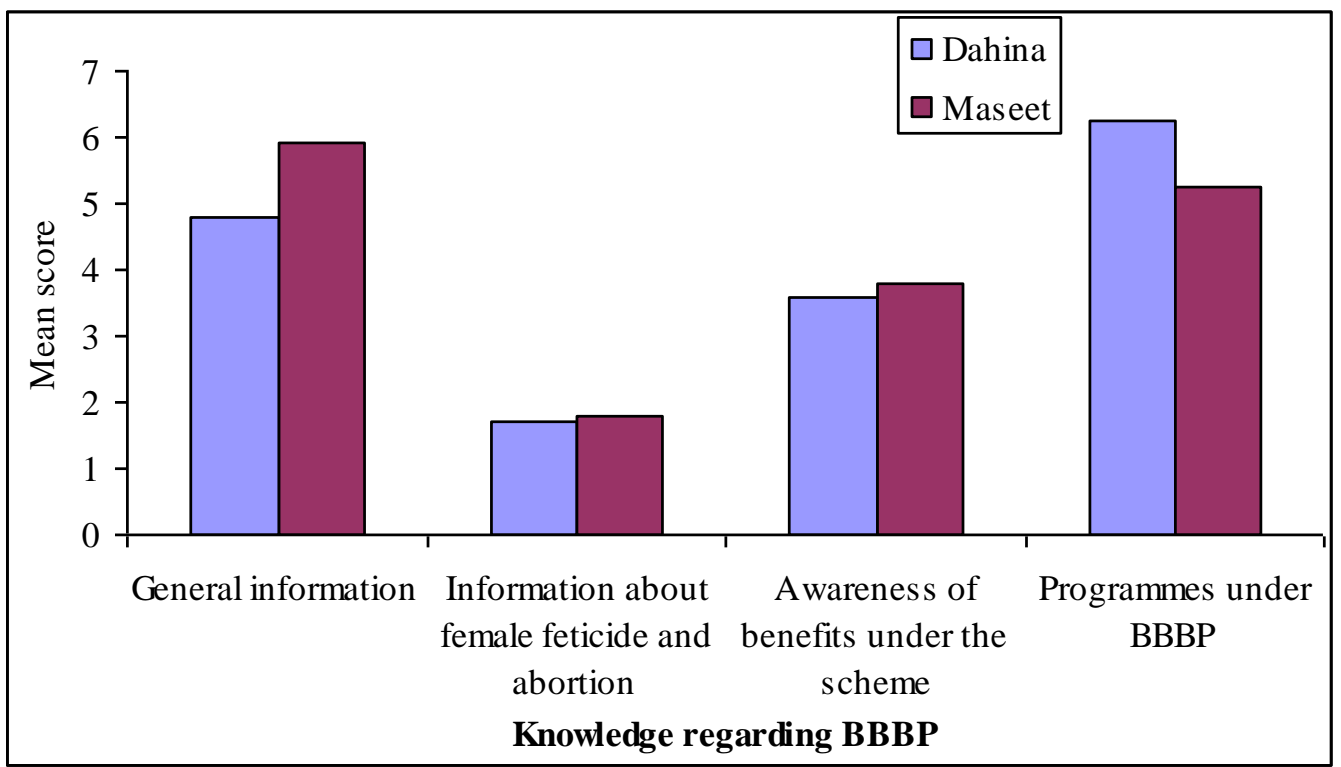

Table 2 further shows awareness about benefits of the scheme. Majority of the respondents had an increase in knowledge for the components that the scheme is assures protection, education, survival, nutritional status of girl child followed by, reward of Rs. 1crore for an innovative village attaining a balanced sex ratio, make girl child aware of sanitation and other health aspects, reduction in rape cases, crimes against girl child, awareness about rights of women and girl child, important for development of girl child, beneficial for both rural as well as urban girl child, in Maseet village. It may, therefore be concluded that women succeeded in acquiring knowledge after exposure. Most of the components were statistically significant at the $5 \%$ level of significance.

Awareness about programme under $B B B P$ showed the maximum increase in knowledge for provision of award in $B B B P$ followed by Haryana kanya kosh and Sukanya Samiridhi Yojna. It may, therefore be concluded that women succeeded in acquiring knowledge after exposure to Programmes under $B B B P$.
All the components were statistically significant at level of 5\% level of significance (Table 3).

The general awareness of the respondents regarding $B B B P$ was low at pre exposure stage, however at post exposure stage, the awareness of the respondents on aspect; female feticide, girls' education, programmes under $B B B P$ and awareness about benefits under the $B B B P$ was considerably high. These finding are in accordance with the findings of Aishwarya et al., (2010) who conducted the study in selected Bikaner Panchayat Samiti of Bikaner district (Rajasthan) to assess the awareness of the rural and urban women about female feticide. The findings revealed that (55\%) rural respondents and (70\%) urban respondents had medium awareness about female feticide.

The difference between pre and post exposure, mean score of knowledge were statistically significant so the respondents were succeeded in acquiring knowledge. The findings were supported by Karwasra and 
Sangwan (2003) who concluded that the difference in pre-exposure and post exposure knowledge and attitude score were highly significant.

In conclusion, sufficient increase in knowledge regarding $B B B P$ was recorded for sub- components viz., general information, information about female feticide and abortion, awareness about benefits given under the scheme, provision of award under BBBP. Computed ' $\mathrm{t}$ ' values were significant at 0.05 per cent level of significance. Thus, it can be inferred that respondents succeeded in acquiring knowledge after exposure.

\section{References}

Aishwarya, D. and Archana, S.R. 2010. Awareness of rural and urban women about female foeticide. Journal of Indian Research, 3(4): 10-12.

Lakshminarayan, M.T., Krishanmurthy, B. and Banuprakash, K. G. 2011. Changing roles of public sector in agriculture extension management, Abstract in International Conference Innovative Approach for Agricultural Knowledge Management, Pp. 347.

Manhas, S. and Banoo, J. 2013. Perceptions related to female foeticide among doctors from Muslim community in Jammu, J\&K. (India). International Indexed and Refereed Research Journal. 4(40):7-9.

Karwasara, S. and Sangwan, V. 2003. Impact of household sanitation technology package in slum areas of Delhi. $J$. Family Ecology. 5(1\&2): 46-48.

\section{How to cite this article:}

Jyoti Rani, Manju Dahiya and Beena Yadav. 2019. Awareness Regarding Beti Bachao Beti Padhao Scheme in Rewari Districts. Int.J.Curr.Microbiol.App.Sci. 8(07): 2299-2305. doi: https://doi.org/10.20546/ijcmas.2019.807.280 